\title{
Differences in Root Resorption between Root Conal treated and contralateral vital tooth during Orthodontic Tooth Movement: A Sustematic Review
}

\author{
Dr Liu Yang,' Dr Sanjay Kumar Tiwari,2 Dr Li Peng³ \\ 'Resident, Dept of Endodontics, Peking University School \& Hospital of Stomatology, Beijing, China \\ ${ }^{2}$ PhD student, ${ }^{3}$ Assoc Prof, Dept of Endodontics, West China College of Stomatology, Sichuan, China
}

\section{ABSTRACT}

It is believed that root canal treated tooth apex goes under more resorption than contralateral vital tooth during orthodontic movement. The concept is still contradictory and therefore the aim of this systematic review was to search the evidence regarding this issue. The clinical trials performed on human subjects with vital and contralateral root canal treated tooth were included in the study. The evidence was searched in PubMed, EMBASE, Medline, Cochrane and Scopus. No language barrier was imposed. From analysis it found that there was no difference in amount of root resorption between vital and contralateral tooth. But, degree of resorption was determined by the intensity of force applied, force application technique (continuous or interrupted), duration of force application and direction of force application. Form the above fact it can be concluded that root canal treated tooth can be moved equal distance as vital contralateral tooth.

Keywords: dental pulp, orthodontic tooth movement, pulp blood flow, root canal treatment, root resorption

\section{INTRODUCTION}

Root canal treatment is a procedure carried on the tooth with necrosed pulp. The common reason of pulp necrosis is entry and colonization of bacteria in pulp chamber. The extension of bacteria and bacterial product from infected root canal to the surrounding periodontal ligament area causes apical periodontitis, and lesion forms after surrounding bone, dentinal hard tissue and periodontal attachment is resorbed. American Association of Endodontics describes resorption as the physiologic or pathologic loss of cementum and dentin from root.' Orthodontic force moves the teeth within the bone confinement. During orthodontic tooth movement, resorption of root apex is common undesired outcome.

The search in this systematic review is framed under PICO format [problem (p), intervention (i), comparison(c) and outcome (o)]; which are as follows: on patient undergoing orthodontic treatment, does a root canal treated tooth compared to vital tooth, results any difference in pattern and amount of root resorption, and does this resorption increases the susceptibility of root canal treatment failure.

The detailed information on outcome of root canal treated tooth when subjected to the orthodontic movement is sparse. The clear picture on the amount of resorption that occurs on root canal treated tooth and the fate of existing previous apical seal is still not clear. Thus, the objective of this review is to explore the answers to the questions raised on the root canal treated tooth.

\section{Literature search of clinical trials}

Search were under taken on PubMed, EMBASE, MEDLINE database and six data bases [Networked Digital Library of
Theses and Dissertation, Proquest Digital Dissertations, OAlster, Index to Theses, Australian Digital Theses program (Dissertation. com) and one conference report database (BIOSIS Preview $\left.{ }^{\circledR}\right)$ ]. Root canal treatment, root canal therapy, endodontic treatment, pulpectomy, orthodontic tooth movement and root resorption were medical search headlines (MeSH) used to retrieve the related articles. The strategy of systematic review was adopted from Cochrane Handbook of Systematic Reviews of Interventions. ${ }^{2}$

A forward search was undertaken from the Science Citation Index (http://www.isinet.com) and Research gate (http:// www.researchgate.net), while references lists of included studies were used for backward search.

We included clinical trial conducted as split-mouth protocol on same patients and compared the amount of root resorption after orthodontic treatment in both vital tooth and contralateral root canal treated tooth. Articles published in all language were included for analysis. Two reviewers (LY and SKT) individually reviewed and collected the relevant studies, retrieved data and analyzed bias in included studies. The presence of bias was followed according Cochrane Handbook of Systematic Reviews of Interventions. ${ }^{2}$ Disagreement between two reviewers (LY and SKT) during data retrieval and analysis was resolved by the discussion: if no agreement could be reached, third reviewer (LP) reviewed the protocol and analysis; and made the final decision.

The statistical analysis of the included studies was not performed because due to heterogeneity among the studies. Thus, the aim of this review was shifted to search the biological reasons of root resorption during orthodontic movement rather than statistical analysis. 
Table 1: Summary of included studies

\begin{tabular}{|c|c|c|}
\hline Study & Methods & Result \\
\hline $\begin{array}{l}\text { Spurrier et al, }{ }^{3} \\
1990\end{array}$ & $\begin{array}{l}\text { Pre- and Post-orthodontic treatment radiographs were } \\
\text { compared for analysis. } \\
\text { Calculations were done by measuring the difference in root } \\
\text { length between pre- and post-treatment radiographs. } \\
\text { All teeth were measured from incisal edge to root apex in pre- } \\
\text { and post-orthodontic treatment radiographs. } \\
43 \text { patients, incisors included for study. }\end{array}$ & $\begin{array}{l}\text { Vital incisor teeth resorbed signifi- } \\
\text { cantly more than contralateral } \\
\text { root canal treated teeth. }\end{array}$ \\
\hline $\begin{array}{l}\text { Mirabella \& Artun, }{ }^{4} \\
1995\end{array}$ & $\begin{array}{l}\text { Calibration of study: same as Spurrier et } a^{3} \\
500 \text { patients, Age: } 20-70 \text { years } \\
\text { Duration: } 0.6-5.2 \text { years. }\end{array}$ & $\begin{array}{l}\text { The teeth with previous root ca- } \\
\text { nal treatment had less resorption } \\
\text { than contralateral vital teeth. }\end{array}$ \\
\hline Esteves et al, 2007 & $\begin{array}{l}\text { Calibration of study: same as Spurrier et a }{ }^{3} \\
16 \text { patients, Active orthodontic treatment duration: minimum } 20 \\
\text { months. }\end{array}$ & \multirow{3}{*}{$\begin{array}{l}\text { No significant differences were } \\
\text { observed between vital and } \\
\text { non-vital contralateral teeth. }\end{array}$} \\
\hline $\begin{array}{l}\text { Llamas-Carreras et al, }{ }^{6} \\
2010\end{array}$ & $\begin{array}{l}\text { Calibration of study: same as Spurrier et } a^{3} \\
77 \text { patients, Age: } 32.7 \pm 10.7 \text { years. } \\
\text { Duration of treatment: } 26.8 \pm 8.9 \text { months. }\end{array}$ & \\
\hline $\begin{array}{l}\text { Llamas-Carreras et al, } \\
2012\end{array}$ & $\begin{array}{l}\text { Calibration of study: same as Spurrier et } a^{3} \\
38 \text { patients, Age: } 30.7 \pm 10.2 \text { years. } \\
\text { Duration of Treatment: } 24.0 \pm 12.0 \text { months. }\end{array}$ & \\
\hline
\end{tabular}

Figure 1: PRISMA flow diagram
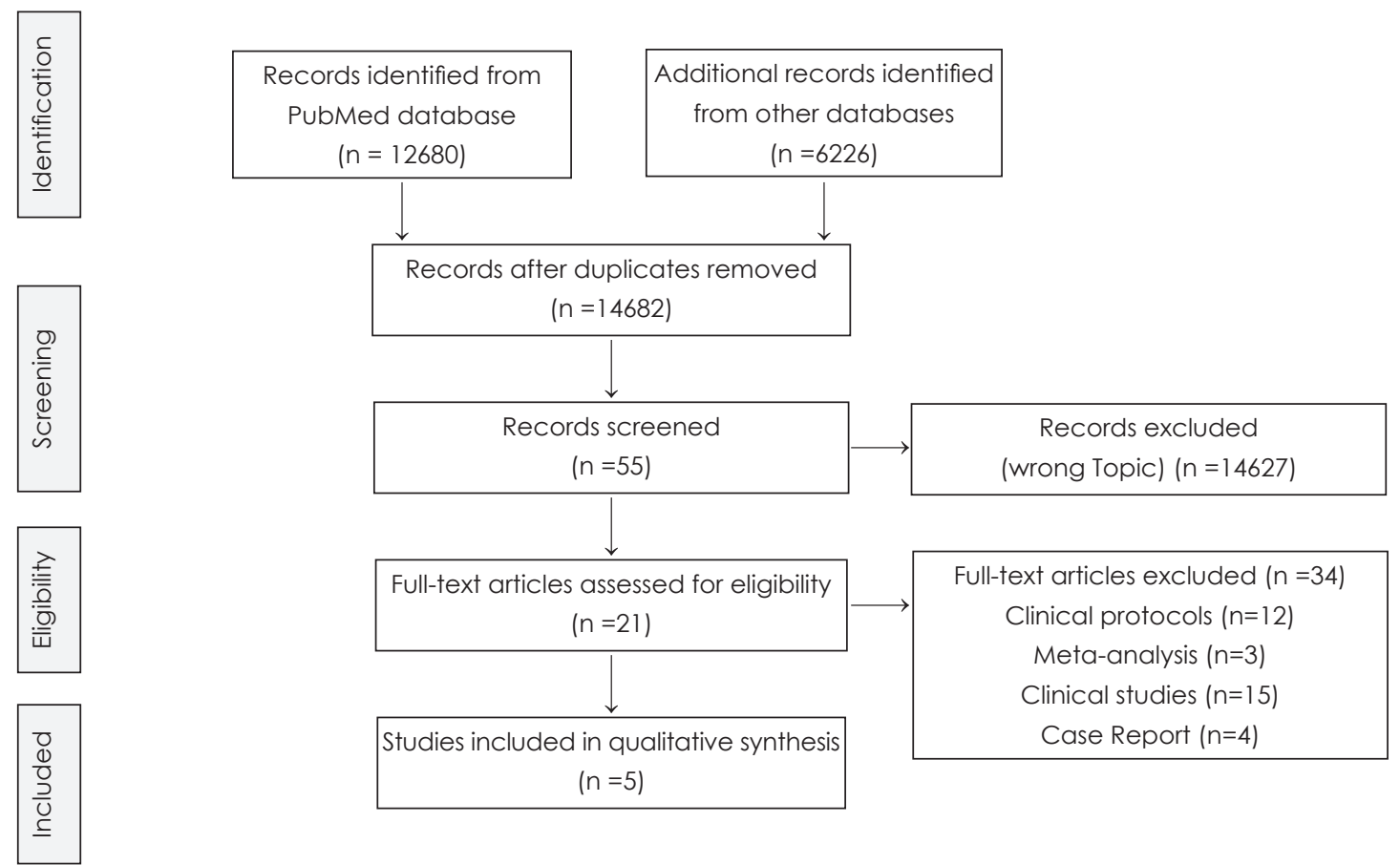

$$
(n=5)
$$

\section{RESULT}

Five studies performed as split-mouth design were retrieved and included for the analysis. ${ }^{3-7}$ Figure 1 shows the methodology adopted for study retrieval. Methodology of the study selection was adopted from PRISMA 2009 flow diagram. ${ }^{8}$ The characteristic of included studies is present in Table 1. Reviewed articles state that the root canal treated teeth were least resorbed than the vital counterpart and apical resorption did not disrupt the apical seal. 


\section{DISCUSSION}

The objective of this review was to analyze the differences in apical root resorption between vital tooth and root canal treated tooth during orthodontic movement, thus to search the reason for resorption. After the search of all forementioned data bases, five selected articles were retrieved. ${ }^{3-7}$ The studies were conducted on human subjects and were designed as split-mouth technique. The split-mouth technique eliminates the possibility of inter-personal bias and provides the strength to the study design.

Although the results of the included studies were consistent but the methods adapted to analyze external root resorption was not uniform. Differences were found in image study, standardization of pre-treatment and post-treatment radiographs, study method of external root resorption and type of teeth included for analysis. Due to the presence of these variations among the studies, the considerable result could not be retrieved. Therefore, we designed the analysis based on the histological and biochemical studies rather than the statistical analysis.

External root resorption is an undesired side-effect during orthodontic tooth movement. Histological studies revealed that more than $90 \%$ of root apex undergo resorption during orthodontic treatment. ${ }^{9-10}$ Bone is under the constant process of remodeling due to the presence of osteoblast and osteoclast within it but such process is absent in cementum because of its devoid of cementoclast cells. Osteoclasts get activated immediately after force application but cementoclasts need to be formed from hemopoietic progenitor cells. Cementoclasts progenitor cell is delivered to the desired area by increased blood flow, either by vasodilatation or by angiogenesis. Expression of endothelial stimulating growth factors in affected area is confirmed from previous studies. ${ }^{11-13}$ Progenitor cells delivered to the affected site first resorb precementum, then cementum and finally dentin:14 and this mechanism of apical root resorption is similar among vital and root canal treated teeth.

It is believed that the pulp neuropeptides play an important role in apical root resorption. Calcitonin gene related peptide (CGRP) and substance-P (SP) are two groups of neuropeptides released when tooth is subjected to orthodontic forces. ${ }^{15}$ CGEP is potent peptide vasodilator and function in transmission of pain, ${ }^{16,17}$ while $\mathrm{SP}$ is associated with inflammatory process and pain. The duel actions of these two molecules provoke tolerable discomfort in patient following active orthodontic treatment. The release of neuropeptides stimulates clastic cells (osteoclasts and cementoclasts) to resorb alveolar bone and cementum. Root canal treated tooth is devoid of pulp tissue thus they show less apical root resorption in compare to the contralateral vital tooth ${ }^{18}$ and this could be the reason why studies found comparatively less resorption with root canal treated tooth. ${ }^{3-7}$
Duration of active tooth movement and amount of force applied are the two critical factors governing amount of root resorption. In 1930, Schwarz proposed that orthodontic force less than or equal to capillary pressure is sufficient to maintain the vitality of tooth. ${ }^{19}$ Force exceeding this limit causes collapse of capillaries, disrupt the blood supply to pulp and initiate apical root resorption. ${ }^{20,21}$ It is also noticed that the amount of apical root resorption and the intensity of force applied are directly related. ${ }^{22,23}$ If the duration of continuous force on the tooth is prolonged; considerable apical root resorption is seen. ${ }^{23,24}$ Therefore, it is advised to apply intermittent force and provide adequate time for repair which will minimize the severity of apical root resorption and pulpal consequences. ${ }^{25,26}$

Tooth with the history of trauma before orthodontic treatment shows more apical resorption and possibility of tooth to be non-vital is high. ${ }^{27-30}$ The possibility of loss of vitality is more in tooth with obliterated canal. ${ }^{30,31}$ Tooth with vital pulp or unobliterated pulp after trauma responds similar to normal vital tooth. ${ }^{27}$ However, still the conclusive remark could not be made on the prognosis of orthodontic tooth movement in traumatized tooth due to lack of randomized controlled clinical trial.

\section{CONCLUSION}

Based on the current review; it can be concluded that:

1. The orthodontic force can cause inflammatory and/ or degenerative changes in dental pulp. The prognosis of tooth depends on the duration and amount of force applied.

2. No significant differences in amount and severity of resorption were seen between vital and root canal treated tooth with equal amount of force application. This outcome was seen in well cleaned, shaped and obturated tooth, and tooth with no coronal leakage or no path for bacterial access to periapical tissue.

3. The traumatized tooth can be moved orthodontically with minimal risk if the pulp is vital. The tooth exhibiting signs and symptoms of pulp pathology must undergo root canal treatment before orthodontic treatment.

4. If the root apex of traumatized tooth exhibits resorption before orthodontic treatment, the possibility of farther resorption during treatment is high.

5. Rest period should be provided between active orthodontic tooth movement which will allow the resorbed cementum to heal. 


\section{REFERENCES}

1. AAE Glossary of Endodontic Terms (Revised 2011).

2. Editors: Julian PT Higgins and Sally Green. Cochrane Handbook for Systematic Reviews of interventions, Versions 5.1.0 [updated March $2011]$.

3. Spurrier SW, Hall SH, Joondeph DR, Shapiro PA, Riedel RA. A comparison of apical root resorption during orthodontic treatment in endodontically treated and vital teeth. Am J Orthod Dentofacial Orthop. 1990; 97:130-4.

4. Mirabella AD, Artun J. Risk factors for apical root resorption of maxillary anterior teeth in adult orthodontic patients. Am J Orthod Dentofacial Orthop. 1995; 108:48-55.

5. Esteves T, Ramos AL, Pereira CM, Hidalgo MM. Orthodontic root resorption of endodontically treated teeth. J Endod. $2007 ; 33: 119-22$.

6. Llamas-Carreras JM, Amarilla A, Solano E, Velasco-Ortega E, Rodríguez-Varo L, Segura-Egea JJ. Study of external root resorption during orthodontic treatment in root filled teeth compared with their contralateral teeth with vital pulps. Int Endod J. $2010 ; 43: 654-62$.

7. Llamas-Carreras JM, Amarilla A, Espinar-Escalona E, Castellanos-Cosano L, Martín-González J, Sánchez-Domínguez B, López-Frías FJ. External apical root resorption in maxillary root-filled incisors after orthodontic treatment: A split-mouth design study. Med Oral Patol Oral Cir Bucal. 2012; 17:523-7.

8. Moher D, Liberati A, Tetzlaff J, Altman DG, The PRISMA Group (2009). Preferred Reporting items for Systematic Reviews and Meta-analysis: The PRISMA statements. PLOS Med 6(7): e1000097. Available at: URL: www.prisma-statment.org

9. Owman-Moll P, Kurol J, Lundgren D. The effects of a four-fold increased orthodontic force magnitude on tooth movement and root resorptions. An intra-individual study in adolescents. Eur J Orthod. 1996; 18:287-94.

10. Kurol J, Owman-Moll P. Hyalinization and root resorption during early orthodontic tooth movement in adolescents. Angle Orthod. 1998; 68:161-5.

11. Derringer KA, Linden RW. Enhanced angiogenesis induced by diffusible angiogenic growth factors released from human dental pulp explants of orthodontically moved teeth. Eur J Orthod. 1998; 20:357-67.

12. Derringer K, Linden R. Epidermal growth factor released in human dental pulp following orthodontic force. Eur J Orthod. 2007; 29:67-71.

13. Derringer KA, Linden RW. Angiogenic growth factors released in human dental pulp following orthodontic force. Arch Oral Biol. 2003; 48:285-91.

14. Brudvik P, Rygh P. Multi-nucleated cells remove the main hyalinized tissue and start resorption of adjacent root surfaces. Eur J Orthod. $1994 ; 16: 265-73$.

15. Caviedes-Bucheli J, Moreno JO, Ardila-Pinto J, Del Toro-Carreño HR, Saltarín-Quintero H, Sierra-Tapias CL, Macias-Gomez F, Ulate E, Lombana-Sanchez N, Munoz HR. The effect of orthodontic forces on calcitonin gene-related peptide expression in human dental pulp. J Endod. 201 1; 37:934-7.

16. Raddant AC, Russo AF. Calcitonin gene-related peptide in migraine: Intersection of peripheral inflammation and central modulation. Expert Rev Mol Med. 2011; 13:e36.

17. Cady RJ, Glenn JR, Smith KM, Durham PL. Calcitonin gene-related peptide promotes cellular changes in trigeminal neurons and glia implicated in peripheral and central sensitization. Mol Pain. $2011 ; 7: 94$.

18. Bender IB, Byers MR, Mori K. Periapical replacement resorption of permanent, vital, endodontically treated incisors after orthodontic movement: report of two cases. J Endod. 1997; 23:768-73.

19. Schwarz AM. Tissue changes incidental to orthodontic tooth movement. Int J orthod. 1932; 18:331-52.

20. Hohmann A, Wolfram U, Geiger M, Boryor A, Sander C, Faltin R, Faltin K, Sander FG. Periodontal ligament hydrostatic pressure with areas of root resorption after application of a continuous torque moment. Angle Orthod. 2007; 77:653-9.

21. Reitan K. Some factors determining the evaluation of forces in orthodontics. Am J orthod. 1957; 43:32-45.

22. Kurol J, Owman-Moll P, Lundgren D. Time-related root resorption after application of a controlled continuous orthodontic force. Am J Orthod Dentofacial Orthop. 1996; 110:303-10.

23. Paetyangkul A, Türk T, Elekdağ-Türk S, Jones AS, Petocz P, Darendeliler MA. Physical properties of root cementum: part 14. The amount of root resorption after force application for 12 weeks on maxillary and mandibular premolars: a microcomputed-tomography study. Am J Orthod Dentofacial Orthop. 2009; 136:492.e1-9.

24. Paetyangkul A, Türk T, Elekdağ-Türk S, Jones AS, Petocz P, Cheng LL, Darendeliler MA. Physical properties of root cementum: Part 16. Comparisons of root resorption and resorption craters after the application of light and heavy continuous and controlled orthodontic forces for 4, 8, and 12 weeks. Am J Orthod Dentofacial Orthop. 2011; 139:279-84.

25. Ballard DJ, Jones AS, Petocz P, Darendeliler MA. Physical properties of root cementum: Part 11. Continuous vs intermittent controlled orthodontic forces on root resorption. A microcomputed-tomography study. Am J Orthod Dentofacial Orthop. 2009; 136:8.e 1-8.

26. Aras B, Cheng LL, Turk T, Elekdag-Turk S, Jones AS, Darendeliler MA. Physical properties of root cementum: part 23. Effects of 2 or 3 weekly reactivated continuous or intermittent orthodontic forces on root resorption and tooth movement: a microcomputed tomography study. Am J Orthod Dentofacial Orthop. 2012; 141:29-37.

27. Malmgren O, Goldson L, Hill C, Orwin A, Petrini L, Lundberg M. Root resorption after orthodontic treatment of traumatized teeth. Am J Orthod. 1982; 82:487-91.

28. Bauss $O$, Röhling J, Sadat-Khonsari R, Kiliaridis S. Influence of orthodontic intrusion on pulpal vitality of previously traumatized maxillary permanent incisors. Am J Orthod Dentofacial Orthop. 2008; 134:12-7.

29. Bauss O, Schäfer W, Sadat-Khonsari R, Knösel M. Influence of orthodontic extrusion on pulpal vitality of traumatized maxillary incisors. J Endod. 2010; 36:203-7.

30. Brin I, Ben-Bassat Y, Heling I, Engelberg A. The influence of orthodontic treatment on previously traumatized permanent incisors. Eur J Orthod. 1991; 13:372-7.

31. Bauss $\mathrm{O}$, Röhling J, Rahman A, Kiliaridis S. The effect of pulp obliteration on pulpal vitality of orthodontically intruded traumatized teeth. J Endod. 2008; 34:417-20. 